\title{
Strategic approaches to informing the public about biotechnology in Latin America
}

\author{
Patricia L. Traynor \\ New Agritech Strategies \\ P.O.Box 10173 \\ Blacksburg VA 24062 \\ Virginia, USA \\ Tel: 5405525374 \\ Fax: 5409612629 \\ E-mail: traynor@texnet.net \\ Marta Adonis \\ Cellular and Molecular Biology Program \\ Institute of Biomedical Sciences \\ Faculty of Medicine, University of Chile \\ Independencia 1027, Santiago, Chile \\ Tel: 5629786061 \\ Fax: 5627356373 \\ E-mail: 1gil@med.uchile.cl \\ Lionel Gil* \\ Cellular and Molecular Biology Program \\ Institute of Biomedical Sciences \\ Faculty of Medicine, University of Chile \\ Independencia 1027, Santiago, Chile \\ Tel: 562978 6068/6413 \\ Fax: 5627356373 \\ E-mail: lgil@med.uchile.cl
}

\begin{abstract}
Financial support: This work has been supported by OAS Project Number AE-192-4: Capacity Building for the Safe and Sustainable use of Biotechnology, within the Framework of the Biosafety Protocol.
\end{abstract}

Keywords: biotechnology, GMOs, public perception.

The benefits of today's biotechnology products are not evident to consumers. The public will accept biotechnology only when individuals decide for themselves that biotec products will contribute to their personal well-being. To make such a decision, people will need greater awareness and understanding of how biotechnology will affect the environment, human health, local and national economies, and the well-being of society. A low level of awareness and understanding about biotechnology is characteristic of Latin America and the Caribbean countries, as elsewhere, efforts to remedy poor public perception often seem inadequate and do not reflect a well-designed strategy.

In order to improve the understanding of the biotechnology and their human applications, a strategic plan for public communications is required. Specific objectives for this initiative may include: (1) to make evident to decision makers that modern biotechnology can be an effective tool for increasing agricultural productivity, and thereby economic growth, without imposing unacceptable risk to the environment or human and animal health; (2) to enable members of the public to make informed decisions about appropriate uses of biotechnology by providing accurate information about benefits, risks and impacts; or (3) to incorporate modern biotechnology into science curricula for secondary schools, university and college students, and agriculture extension officers.

A variety of specialized expertise, including communication specialists, technical writers, graphic artists and illustrators to design information materials and conduct training is needed to implement this. Ideally, members bring expertise in biotechnology and biosafety, public communications and project management. The plan will need to identify scientists and technical experts who can provide expertise in science writing for general audiences, advertising, graphic arts, public opinion polling and media communications. These people can provide basic information about the techniques of modern

*Corresponding author 
biotechnology; the products now available and those being developed; what is known about the nature, probability and consequences of potential risks. Governments, industry, universities and media must play an important role to improve public perception about biotechnology, this is a requirement to develop biotechnology in the Region.

The products of modern biotechnology, most notably genetically engineered agricultural crops and foods derived from them, are becoming increasingly common in Latin America and the Caribbean. Farmers in Argentina are among the world leaders in adopting the new technology, Brazil is making rapid strides in genetically modified (GM) crop production, and research in numerous countries in the region is advancing new varieties of GM fruits, grains and vegetables into the field for testing (Bonalume, 2003; Capalbo et al. 2003; Freitas et al. 2003; De A Dos Santos et al. 2005).

Compared with the rapid rate of farmer adoption, however, public acceptance of genetic engineering technology as applied to agriculture, and especially GM foods, lags behind. While acceptance of applications in medicine and health or environmental remediation tends to be somewhat higher, the public has yet to embrace modern biotechnology (Gil et al. 2000). Exaggerated claims, misperceptions, inaccurate and sometimes false information, oversimplification, lack of awareness, lack of transparency, and lack of certainty cloud the public debate over the use of modern biotechnology. Most importantly, the benefits of today's biotechnology products are not evident to consumers.

A low level of awareness and understanding about biotechnology is characteristic of developing and developed countries alike (Finucane and Holup, 2005; Pidgeon et al. 2005; Purchase, 2005). In Latin America and the Caribbean, as elsewhere, efforts to remedy poor public perception often seem inadequate and do not reflect a welldesigned strategy. Diverse, unrelated and uncoordinated activities (public discussion events, print materials, conferences, media coverage, town meetings, demonstrations, workshops, etc.) may vary greatly in quality and effectiveness. The timing may be wrong, as when farmers learn about the agronomic benefits of GM crops, but approval for GM seed commercialization is not expected for some years. The activity may not fit the audience, as in a technical biosafety training course for farmers or policy makers. There may be no provision for follow-up support, such as a biotechnology information center. Because resources are limited, planning for information activities may be minimal and based in part, on what has been done in the past, with little or no assessment of its effectiveness. In some cases, information initiatives appear to be designed elsewhere, without local input on formats and delivery mechanisms known to be successful in the country.
The remedy to confusion, misunderstanding and ignorance is information-accurate, meaningful and useful information that will increase people's awareness and understanding of modern biotechnology. Such knowledge enables people to make better informed decisions as to how, when and where biotechnology should be used.

\section{ADOPTION OF GM CROPS IN SIX LATIN AMERICAN COUNTRIES}

Brazil and Argentina are among the world's five leading developing countries that have approved and adopted biotech crops (the others are China, India and South Africa). As such, they will have a significant impact on the future adoption and acceptance of biotech crops globally (ISAAA, 2004; James, 2004). Argentina, with 17.1 million hectares planted in 2005, is the world's second leading country in biotechnology crop adoption (ISAAA, 2005). Brazil in 2005 planted 4.4 millions hectares more than in the previous year, the largest annual increase in biotech crop production by a country in 2005 (ISAAA, 2005).

\section{Argentina}

The government of Argentina has designated biotechnology as one of eight strategic areas for national development. Data from 2003/2004 (ISAAA, 2005) show that the combined value of Argentina's genetically engineered soybeans, cotton and maize was US\$ 8.9 billion, making Argentina the world's second ranking country by value of biotech crop production. Adoption of GM crops in Argentina began in 1996 with government approval for commercial-scale production of glyphosate tolerant variety of soybean (Hammond et al. 1996; Cerdeira and Duke, 2006) and insect resistant maize (Wisniewski et al. 2002); the GM crops were for export only. Cotton (Perlak et al. 1990) and maize varieties resistant to lepidopteran pests and an herbicide tolerant maize line were approved for commercial large-scale production in 1998. In 2001, herbicide tolerant cotton and a new insect resistant maize were approved. Additional approvals for GM maize lines followed in 2004 and 2005, including one variety both insect resistant and herbicide tolerant. Herbicide tolerant soybean was granted food safety approval in 2004, which opened the door for domestic sale and consumption.

In $2005-2006,65 \%$ of the total maize crop was genetically engineered for insect resistance and another 3\% was herbicide tolerant. Fully $99 \%$ of the soybean crop was engineered for herbicide tolerance; estimates for the percentage of cotton that was GM are not yet available. Additional crops and traits are being developed. Field trials have been conducted on alfalfa, cotton, maize, potato, soybean, sugar beet, sunflower, tomato and wheat. Lab experiments have been undertaken on alfalfa, barley, potato and sugar cane. 


\section{Brazil}

In 2003/2004, GM soybean varieties were officially approved in Brazil for production in certain Southern states. However, farmers for several years had been able to acquire seeds for herbicide tolerant soybeans through unofficial channels. Of the 53.5 million metric tons of soybeans produced in 2003-2004, official statistics indicate biotech varieties comprised about $12 \%$ of the crop; unofficial estimates put the adoption rate as high as $30 \%$. In Rio Grande do Sul, Brazil's third-ranking state in soybean production, some estimates put biotech adoption rates at $90 \%$.

Field trials have been conducted on 27 other crops, including virus resistant common bean, papaya, potato, tobacco, sugarcane and tomato; herbicide tolerant soybean, common bean, cotton, maize, rice, and sugarcane; insect resistant $(\mathrm{Bt})$ cotton, maize, soybean and sugarcane. Some maize, cotton and sugarcane varieties are engineered with multiple traits. With 9.4 million hectares planted in 2005, Brazil is the world's third-ranking country for planting biotech crops.

\section{Chile}

Since the first field trials for GM seed production in 1992, Chile has become a "winter nursery" for major seed producers. Currently, the country grows about 10000 hectares of GM crops for seed production, all of which is exported. Most of the varieties are engineered for herbicide tolerance, insect resistance, or the combination of both traits. All field tests and seed production of GM varieties are subject to approval by the Livestock and Agricultural Service (SAG) in accordance with Resolution $\mathrm{N}^{\mathrm{o}} 1525$, which regulates the introduction of Genetic Modified Organisms (GMOs) into the environment in compliance with biosafety measures. As of early 2006, approval for commercial use of GMOs in Chile has not yet been granted. Such approvals cannot be granted prior to the adoption of the Biosafety Law that must be discussed by the new Parliament during 2006.

Public and private biotech investment is in the range of US\$ 50 million a year. Plant biotech research is underway in government and academic institutions, as well as over 30 private sector companies. Laboratory studies are being conducted on genetically engineered fungus resistant apple, grape, and garlic, virus resistant melon, potato and tomato, modified ripening stone fruits, and tomato and tobacco engineered with various new traits. Chile, a major fruit exporter with almost US\$2.0 billion in sales in 2005, anticipates an export platform for biotech fruit by 2008 .

\section{Colombia}

As of 2005, Colombia ranks $15^{\text {th }}$ in the world with just under 0.05 million hectares of biotech crops (ISAAA, 2005). The first application for growing a GMO in
Colombia, a carnation engineered for blue flower colour, was approved in 2000. Colombia's first field trials of a GM crop (Bt Bollgard cotton) were conducted in 2002. Commercial planting of Bollgard and Roundup Ready cotton were authorized in 2003 and 2004, respectively. In 2005 , risk assessment was initiated for cotton Bollgard + Roundup Ready cotton, Bollgard II + Roundup Ready flax, YieldGard corn, Roundup Ready corn, Bt11 corn and Bt Herculex (Cry1F) corn. Bollgard cotton, Round-up Ready cotton, and YieldGard and Round-up Ready corn have been approved for animal feed.

Research conducted under conditions of confinement-in greenhouses or small-scale field trials-is proceeding on numerous fronts. Transgenic roses and carnations exhibiting modified flower colour are approved for greenhouse studies. Confined studies have been approved for Brachiaria grass resistant to salivazo (Aeneolamia sp, an insect pest that attack sugar cane and tropical grass), rice resistant to white leaf virus, and cassava resistant to stem borer. In addition, small scale field studies for sugar cane resistant to yellow leaves virus, as well as for cassava altered production of cytokines, amylopectin and cyanide have been approved.

Confined research on species other than plants also has been approved. Projects include studies on silk worms genetically engineered to produce human albumin, and DNA vaccines against ticks and the viral pathogen that causes foot and mouth disease in livestock. Risk assessment studies are being done for virus vector vaccines against avian laryngotracheitis and Micoplasma gallicepticum.

Thus, Colombia has been a pioneer country developing a national regulatory system for GMOs before the approval of the Cartagena Protocol. The country has a National Biosafety Committee that analyzes risk assessment case by case. Research on GMOs is done in Universities and Research Institutes.

\section{Ecuador}

In two of Ecuador's three geographical regions, agriculture is a major economic activity. Large farms are found primarily in the coastal region. Some farmers there are willing to try GM crops, while others want to use organic farming methods which, presumably, preclude the use of GM varieties. The Sierra region is home to Indian farmers who have small farms and use practices that are more traditional. In recent years, important areas are being dedicated to flower production, which has changed the use of the soil and agricultural practices. Anti-biotech groups are most active in this part of the country. In the tropical forest region, where the economy is centered on oil exploration and exploitation, agriculture is practiced principally by "colonos," plantation growers who have destroyed big forest regions for this purpose. Local people also practice agriculture on a small scale, more for subsistence and exchange purposes. 
Officially, no GM crops are grown in Ecuador as there is not yet a functional regulatory system. Development and implementation of a system to review and approved uses of transgenic organisms is hindered by regulations that have not yet been finalized, and lack of agreement between all the sectors (public and private) involved in this topic. A recent environmental law designates that the Ministry of Environment is in charge of biosafety related to GMOs. However, the Ministry of Agriculture has also stepped forward to claim authority. This latter issue is a common sticking point for many developing countries.

Students at the University San Francisco in Quito in 2004 conducted an opinion survey of 1200 people between the ages of 18 and 50 who represented three social groups: professionals, craftsmen and academics. No significant differences were found between the responses of the groups. The results demonstrated a lack of knowledge regarding the potential benefits and disadvantages of using or consuming transgenic crops or other organisms. It would be interesting to conduct a new survey targeting young people and consumers, to assess whether the level of awareness and understanding of GMOs has increased, and to what extent it is negative or positive.

\section{Mexico}

Mexico's first commercial biotech crop was Calgene's delayed-ripening tomatoes, grown in 1995. GM cotton resistant to lepidopteran pests was planted in 1996, the same year as the United States. By 2000, biotech cotton accounted for 261300 hectares, one-third of Mexico's cotton-growing area (Traxler and Godoy-Avila, 2004). Glyphosate herbicide tolerant soybeans were produced in 1998. Field studies of numerous vegetable, fruit, fiber and grain crops have been conducted, including transgenic wheat engineered for tolerance to drought, low temperatures, and salinity tested at CIMMYT in March 2004.

A controversial issue in Mexico has been gene flow between maize species. This process can occur between sexually compatible plants and wild relatives if appropriate conditions are met. The genetic modification must increase plant's ability to survive and reproduce in order to be preserved over generations. The debate has been center if in traditional open systems of freely exchanged seed within communities, the GM maize release might result or not in the incorporation of transgenes in the genome of Mexican germplasm and possibly in that of teosinte. In 2001 David Quist and Ignacio Chapela, researchers from UCLA published in Nature a paper describing transgenic DNA introgressed into traditional maize landraces in Mexico (Quist and Chapela, 2001). Due to many letters received, the Nature editor apologized for publishing the paper and claiming that was a failure in the methodology. Baltazar et al. 2005 have claimed that gene flow between maize and its wild relatives does occur, but at very low frequencies. Whereas, Serratos-Hernárdez et al. 2004 have concluded that the most likely outcome of GM maize release is the incorporation of transgenes in the genome of Mexican germplasm and possibly in that of teosinte. The debate is not ended and clearly further studies are need.

\section{STRATEGIC APPROACHES TO INCREASE PUBLIC AWARENESS AND UNDERSTANDING OF BIOTECHNOLOGY}

Inadequate information is the most often cited impediment to the public's awareness and understanding of modern biotechnology. To complicate matters, certain basic facts seem to have been lost in the controversy, allowing misleading ideas to persist. In the context of providing information about biotechnology, communicators must highlight such facts as:

- Biotechnology is a tool for crop improvement, not a solution for hunger or poverty.

- Conventional agriculture is not benign; it is the world's leading cause of loss of biodiversity.

- Some common foods can be harmful to eat.

- There is never "zero risk" in any endeavour; guarantees of safety are never possible.

- Appropriate decisions can be made even in the absence of complete knowledge.

- Claims that are not supported by evidence cannot be taken as fact.

Food and environmental safety, labelling, and freedom to choose non-GM foods are major consumer issues that must be addressed wherever transgenic food products are marketed.

Communications about GM products, therefore, must be explicit in explaining how they will benefit individuals and society.

Whether the information being shared is complex or simple, and the audience internal or external, effective communication is governed by a remarkably simple guiding principle: To achieve the desired objective, the communicator must deliver the right information to the right audience. As noted by Massey (personal communication, 2004), a number of operational steps follow logically and sequentially from this principle, the first being to define the objective as precisely as possible. The nature and details of the objective determine the audience; the interests and character of the audience guide the shaping of the information, its packaging, and the most effective conduit for getting the tailored message to the targeted audience.

\section{Getting started}

Certain preliminary tasks performed prior to drafting a strategic communications plan can greatly facilitate the planning process and lead to a more focused and effective 
initiative. The following suggestions are addressed to those responsible for developing a strategic plan.

- Establish a working group to develop the communications plan. Ideally, members bring expertise in biotechnology and biosafety (detailed below), public communications and project management. Individuals who can provide expertise in science writing for general audiences, advertising, graphic arts, public opinion polling and media communications will likely be needed at various stages of the project.

- Identify scientists and technical experts who are knowledgeable about biotechnology, crop breeding, environmental and food safety, and related fields. These people can provide basic information about the techniques of modern biotechnology; the products now available and those being developed; what is known about the nature, probably and consequences of potential risks; the evidence supporting claims of safety or risk; how environmental safety is assessed; how food safety is assessed; and the operations of the national biosafety system.

- Analyze local and national information initiatives in any subject area to determine what strategies work and what does not work in terms of effective information delivery to public audiences. For example, examine recent and current information campaigns in public health (e.g., childhood vaccination programs; HIV-AIDS awareness and prevention; healthy lifestyle promotions; importance of pre-natal care), education (e.g., benefits of staying in school; literacy programs), and environmental protection (anti-pollution; disposal of hazardous materials; protecting and preserving land and water resources). What has made some information initiatives successful? Why have others had little effect? Preliminary analyses will provide valuable insights into designing and implementing an effective plan.

- Obtain an expert assessment of the current or likely impact of GMOs, both positive and negative, on the national economy with respect to export and trade, food security, employment and other relevant social and economic parameters.

- Conduct survey research or update past surveys to establish baseline data on current public perceptions about biotechnology. Knowing the information gaps - what people want or need to know but presently do not know, or are misinformed about - is the essence of a strategic approach. Activities to provide information will be tailored to address these gaps and focus on the concerns expressed by the public.

\section{ELEMENTS OF A STRATEGIC PLAN}

In general terms, a strategic plan for communications typically includes a statement of objectives, identification of target audience(s) and their information needs, proposed activities to achieve the objectives, list of resources needed, and means to assess impact and measure success.

\section{- Statement of objectives.}

A concise statement of the objective(s) is key to the success of a communications plan because it defines the intent, scope and audience. The interests and character of the audience guide the nature of the information provided, its packaging, and means for delivering it to the target audience. With regard to any subject matter, basic communication objectives are:

- To inform people about a subject.

- To provide a mechanism for the public to voice concerns.

- To increase mutual trust and credibility.

- To reduce conflicts or controversies.

- To improve one's own understanding of public values and concerns.

- To respond to inaccurate perceptions.

- To promote informed discussion.

In communicating about biotechnology and biosafety, the objectives of a plan are determined by the priority information needs of the intended audience, priorities and objectives of the sponsoring organization, and the time and resources available. Specific objectives may be, for example, (1) to make evident to decision makers that modern biotechnology can be an effective tool for increasing agricultural productivity, and thereby economic growth, without imposing unacceptable risk to the environment or human and animal health; (2) to enable members of the public to make informed decisions about appropriate uses of biotechnology by providing accurate information about benefits, risks and impacts; or (3) to incorporate modern biotechnology into science curricula for secondary schools, university and college students, and agriculture extension officers. Framing the objectives in concrete terms will guide subsequent decisions on what activities to undertake, and will suggest criteria for evaluating overall impact of the initiative.

- Target audience(s) and their information needs. "The public" is not a homogeneous population; rather it encompasses numerous sub-groups such as farmers, consumers, policy makers, teachers, health professionals, environmentalists and myriad others. Each of these groups constitutes a distinct audience seeking information that answers their questions and concerns with an appropriate level of detail.

- Farmers: How will GM seeds benefit me? Will I need to change my regular farming practices? Will 
I be able to sell my crop if it is GM? Why can I not save GM seed from one season to the next? If I decide not to grow GM crops but my neighbor wants to try GM, how will it affect my crop? What will happen to the farmers knowledge accumulated over thousands of years? Will traditional and local crop varieties be lost?

- Consumers: Are GM foods safe? How do you know? Do they cause allergic reactions? Could they have unknown toxic substances? Do some GM foods have health benefits?

- Policy makers: How will adoption of GM crops affect our international markets and trade? Will we lose an important part of our indigenous culture? Can GM technology bring us closer to food security or self-sufficiency? How will growing GM crops affect our country's native genetic resources? What are the risks of GM varieties in small-scale research studies vs. large-scale, commercial production? How will the use of GM crops affect rural livelihoods?

- Teachers: What is genetic engineering and how is it done? What can scientists do using modern biotechnology? What can they not do? What are the ethical and moral issues raised by genetic engineering?

- Health professionals: What are the long-term effects of eating GM foods? Are they safe for young children below 5 years old? Are they less nutritious than conventional foods? Will exposure of farm workers to pesticides be reduced?

- Environmentalists: How will GM crops affect local ecosystems? How do the risks of growing GM crops compare with the risks of conventional agriculture? What restrictions should be placed on the use of GM seeds? Will GM crops pose a threat to biological diversity? What will be the ecological effect of growing a GM crop variety in the crop's Center of Origin?

Experience has shown that the public's questions, concerns and fears, if ignored or trivialized by biotechnology proponents, can become adversarial issues that are difficult to resolve.

\section{Activities to achieve objectives}

Each target group or audience trusts some communicators but not others, responds to different formats and styles of presentation, and accesses information through preferred channels. Part of a communications strategy is to capitalize on audience preferences in order to maximize the exchange of information.

\section{Spokespersons and communicators}

The choice of communicators deserves special attention as it is key to effective information delivery. Who are the people trusted by each audience? Who lacks credibility?
Audiences will be more receptive to what they hear if it comes from someone they respect and trust. In some places, for example, government authorities may enjoy the public's full confidence. In others, government officials may not be well-respected and may even be viewed with suspicion. Health care professionals and religious leaders often receive high marks for public trust. The public usually considers industry representatives, particularly those from large multi-national seed companies, as being among the least trustworthy sources, regardless of how well-informed they may be. Trusted spokespersons may be found among:

$\begin{array}{lll}\text { - Farmers } & \text { Food retailers } & \text { Celebrities } \\ \text {-Consumer groups } & \text { Teachers } & \text { Extensionists } \\ \text {-TV reporters } & \text { Local officials } & \begin{array}{l}\text { Community } \\ \text { leaders }\end{array} \\ \text { - Scientists } & \begin{array}{l}\text { Environmental } \\ \text { groups }\end{array} & \text { Print journalists } \\ & \end{array}$

Capable, effective biotechnology spokespersons may be difficult to find. Fortunately, good communication skills can be learned. One of the most useful first steps in conducting an information initiative is to create a pool of skilled communicators. Good candidates for communications training should have a basic understanding of the subject matter, but need not have a technical background. A cadre of trained spokespersons can serve as 'information activists' and play a catalytic role in conducting national information initiatives.

\section{Format and delivery options}

Making information available is only part of an information initiative; equally important is packaging it to make it attractive and accessible to the intended audience. Local culture and tradition influence how people prefer to obtain information; accordingly, these factors will guide decisions on how best to formulate and deliver information so that people "get the message". Commonly used formats, such as newspaper articles, panel discussions at public meetings and brochures distributed at conferences, can be effective for certain audiences. Demonstration field plots, displays for farm shows, briefing notes for extensionists and farm radio broadcasts can be used to explain biotechnology to farmers and in rural communities.

A government official may spend less than $30 \mathrm{sec}$ glancing at 10-page report about biotechnology, but may take two min to read a list of bullet points highlighting what is known about the benefits and risks. Newspapers may be a primary information source for educated people, however TV may be a more important source for the general population. Where literacy rates are low, videos, small 
plays or colorful picture stories could be more effective than words in explaining how new, genetically engineered seeds can affect the lives of local people. The scientific society ANBio (the Brazilian Biosafety Association), publishes BIOPOP, a magazine oriented to scientific education, diffusion and popularization of biotechnology. BIOPOP is sent to all public high schools through the Ministry of Education, and has a total circulation of 28000 copies for each issue. Educational curriculum materials, such as those on the web page www.porquebiotecnologia.com.ar, can be developed for different academic levels and adapted for distance learning programs. With a little creativity and imagination, many other means of delivering information can be devised for specific audiences.

\section{Timing and sequence}

Public information efforts in biotechnology are rarely proactive; rather, they usually appear in response to highly visible opposition campaigns seeking to arouse fear and cultivate resistance to the use of GM crops. A pro-active, strategic approach seeks to provide information for particular audiences in a timely manner. A strategic plan determines when and in what order activities are conducted, based on their priority with respect to the stated objectives. Criteria for prioritizing activities might include:

- The nature of the audience and it's role in the adoption of biotechnology (e.g., policy makers should be well-informed before taking political positions).

- Pending legal or regulatory events (e.g., Parliamentarians should be briefed before receiving a draft law).

- Evidence that a lack of information is causing misperceptions to persist (e.g., Ministry officials have information only from Greenpeace; opinion leaders make inaccurate statements about risks and benefits; reporters write articles that show they did not understand what scientists told them).

- Who is requesting information and for what purpose (teachers want a secondary school curriculum; extensionists are getting questions from farmers).

Once a sequence is established, planners can complete an implementation plan that includes for each activity a brief description, the party responsible for organizing the activity, potential partner institutions and collaborators, proposed cost, expected outcomes and/or outputs, and short - and long-term measures of impact.

\section{Resource needs}

Basic resources needed to operate an information initiative (administrative infrastructure, secretarial support, communications, travel, materials and supplies) are similar to other such undertakings, and are not elaborated here.
A strategic plan for public communications requires a variety of specialized expertise. Planners may wish to include communication specialists, technical writers, graphic artists and illustrators to design information materials and conduct training. Professional fees or stipends may need to be budgeted in some cases. Videos are an excellent way to inform and educate, but can be expensive to produce professionally. Budgets for public meetings, conferences, workshops and the like quickly escalate as costs for suitable meeting space, office and presentation equipment, food service, supplies, honoraria and travel are added up.

The frequent solution to limited financial and human resources is to work in partnership with local, national and regional organizations. Early in the planning process is the best time to engage potential partners and identify their specific contributions. Creative approaches to meet resource needs can also stimulate additional interest in biotechnology. For example, rather than hiring a graphic artist to design print materials about food safety, university students enter a competition to design a poster explaining how GM foods are evaluated for safety. Winning entries would be used to illustrate brochures, presentations, classroom posters, calendars and other materials.

\section{Assessing impact and measuring success}

An initial assessment of public perceptions, as noted above, provides a benchmark against which to measure the impact of a public information initiative. The most direct kind of assessment is to survey a sample of people representative of the target group before and after the initiative. Valid results depend on a properly structured questionnaire and survey process. Interestingly, ANBio in Brazil will use the 2006 National Biology Olympic Contest to measure public awareness about biotechnology in secondary school teachers and students, as well as to evaluate their understanding about basic biology applications.

Surveys, however, are only one way to measure success. Various indicators can be used to determine to what extent the objectives have been met. If, for example, one of the objectives is to increase the accuracy and amount of media coverage, measures of success might include evidence of improved quality of reporting by journalists. Has the frequency of newspaper articles about biotechnology increased? Do the articles fairly describe benefits as well as potential risks? Do they include supporting evidence for any claims made and name the source of the information?

If bringing information to farmers and rural communities was one of the objectives, do farmers who have learned about biotech crops show interest in trying GM seeds? Where some government action related to biotechnology was hindered by lack of good information, are betterinformed policy makers now taking appropriate action? Are government leaders publicly showing support for testing and/or use of GM crops? 
Attendance figures for workshops and conferences are often cited as evidence of impact, but the number of attendees in itself is not a measure of success. More rigorous evidence comes from follow-up contact with attendees to assess whether, upon returning to their jobs, they are able to apply what they learned and pass it along to others. Other useful indicators, again depending on the objectives and the activities carried out, might be the number of requests for biotechnology specialists to speak to public, private and government audiences, addition of biotechnology to science education curricula, or scientists publicly refuting false or misleading statements. The ultimate indicator, of course, is the presence of GM foods and foods with GM ingredients in the marketplace, being bought by consumers.

\section{CONCLUDING REMARKS}

When the first GMOs were under development, there was little discussion about public perception. For the most part, biotechnology developers assumed the public would embrace the new technology because its benefits were "obvious"; they dismissed public concerns as irrelevant. All the evidence to date shows exactly the opposite is true. Lack of accurate information about the tangible benefits to be gained from its application to agriculture, industry, medicine and health, and inaccurate perceptions about the nature, magnitude and likelihood of potential risks, have helped create the current climate of public mistrust and resistance.

The public will accept biotechnology only when individuals decide for themselves that GM crops and food products will contribute to their personal well-being. To make such a decision, ordinary people will need greater awareness and understanding of how biotechnology will affect the environment, human health, local and national economies, and the well-being of society. Also key to public acceptance is the establishment of a functional regulatory system having legitimate authority to control use of the technology, and public awareness that such a system operates to protect the environment and human and animal health.

\section{ACKNOWLEDGMENTS}

We acknowledge the comments of Dr. Moises Burachik, SAGPyA, Argentina, Dr. Claudia Forero, ICA, Colombia, Dr. Hector Herrera, OAS Washington DC, Dr. Adrianne Massey, Massey Assoc., Osiris Ocando, Agro-Bio, Colombia, Dr. Lourdes Torres, Catholic University, Ecuador and Gonzalo Pardo SAG, Chile.

\section{REFERENCES}

BALTAZAR, Baltazar M.; SANCHEZ-GONZALES, José de Jesús; DE LA CRUZ-LARIOS, Lino and SCHOPER, John B. Pollination between maize and teosinte: an important determinant of gene flow in Mexico. Theoretical and Applied Genetics, February 2005, vol. 110, no. 3, p. 519-526.

BONALUME NETO, Ricardo. GM confusion in Brazil. Nature Biotechnology, November 2003, vol. 21, no. 11, p. 1257-1258.

CAPALBO, Deise Maria; HILBECK, Angelika; ANDOW, David; SNOW, Allison; BA BONG, Bui; WAN, Fang-Hao; FONTES, Eliana M.G.; ONYANGO OSIR, Ellie.; FITT, Gary P.; JOHNSTON, Jill; SONGA, Josephine; HEONG, Kong Luen and BIRCH, A. Nicholas. Brazil and the development of international scientific biosafety testing guidelines for transgenic crops. Journal of Invertebrate Pathology, June 2003, vol. 83, no. 2, p. 104-106.

CERDEIRA, Antonio L. and DUKE, Stephen O. The current status and environmental impacts of glyphosateresistant crops. Journal of Environmental Quality, September 2006, vol. 35, no. 5, p. 1633-1658.

DE A DOS SANTOS, Claudia B.; DE CARVALHO, Angela C.; RAGOZO, Alessandra M.; SOARES, Rodrigo M.; AMAKU, Marcos; YAI, Lucia E.; DUBEY, Jitender P. and GENNARI, Solange M. First isolation and molecular characterization of Toxoplasma gondii from finishing pigs from Sao Paulo State, Brazil. Veterinary Parasitology, August 2005, vol. 131, no. 3-4, p. 207-211.

FINUCANE, Melissa L. and HOLUP, Joan L. Psychosocial and cultural factors affecting the perceived risk of genetically modified food: an overview of the literature. Social Science and Medicine, April 2005, vol. 60, no. 7, p. 1603-1612.

FREITAS, V.J.; SEROVA, I.A.; ANDREEVA, L.E.; JUNIOR, E.S.; TEIXEIRA, D.I.; CORDEIRO, M.F.; RONDINA, D.; PAULA, N.R.; ARRUDA, I.J.; VERDE, J.B.; DVORIANTCHIKOV, G.; SEROV, O. Birth of normal kids after microinjection of pronuclear embryos in a transgenic goat (Capra hircus) production program in Brazil. Genetic and Molecular Research, May 2003, vol. 2, no. 2, p. 200-205.

GIL, Lionel; IRARRAZABAL, Carlos Y. and MARTÍNEZ, Claudio. Percepción pública de la Biotecnología y de los alimentos derivados de Organismos Genéticamente Modificados en Santiago de Chile. In: GIL, Lionel and IRARRAZABAL, Carlos. eds. Organismos Genéticamente Modificados. Andros Impresores, 2000, p. 233-247.

HAMMOND, B.G.; VICINI, J.L.; HARTNELL, G.F.; NAYLOR, M.W.; KNIGHT, C.D.; ROBINSON, E.H.; FUCHS, R.L. and PADGETTE, S.R. The feeding value of soybeans fed to rats, chickens, catfish and dairy cattle is not altered by genetic incorporation of glyphosate tolerance. Journal of Nutrition, March 1996, vol. 126, no. 3, p. 717727. 
International Service for the Acquisition of Agri-biotech Applications (ISAAA). ISAAA Brief No. 32-2004: Global Status of Commercialized Biotech/GM Crops: 2004.

International Service for the Acquisition of Agri-biotech Applications (ISAAA). ISAAA Brief No. 34-2005: Executive Summary: Global Status of Commercialized Biotech/GM Crops: 2005.

JAMES, C. Preview: Global Status of Commercialized Biotech/GM Crops: 2004. ISAAA Briefs No. 32. ISAAA, Ithaca, NY.

PERLAK, F.J.; DEATON, R.W.; ARMSTRONG, T.A.; FUCHS, R.L.; SIMS, S.R.; GREENPLATE, J.T. and FISCHHOFF, D.A. Insect resistant cotton plants. Biotechnology, October 1990, vol. 8, no. 10, p. 939-943.

PIDGEON, Nick F.; POORTINGA, Wouter; ROWE, Gene; JONES, Tom-Horlick; WALLS, John and O'RIORDAN, Tim. Using surveys in public participation processes for risk decision making: The case of the 2003 British GM Nation? Public debate. Risk Analysis, April 2005, vol. 25, no. 2, p. 467-479.

PURCHASE, Iain F.H. What determines the acceptability of genetically modified food that can improve human nutrition? Toxicology and Applied Pharmacology, September 2005, vol. 207, no. 2, p. 19-27.

QUIST, David and CHAPELA, Ignacio H. Transgenic DNA introgressed into traditional maize landraces in Oaxaca, Mexico. Nature, November 2001, vol. 414, no. 6863 , p. 541-543.

SERRATOS-HERNÁNDEZ, José-Antonio; ISLASGUTIÉRREZ, Fabián; BUENDÍA-RODRÍGUEZ, Enrique and BERTHAUD, Julien. Gene flow scenarios with transgenic maize in Mexico. Environmental Biosafety Research, July-September 2004, vol. 3, no. 3, p. 149-157.

TRAXLER, Greg and GODOY-AVILA, Salvador. Transgenic Cotton in Mexico. AgBioForum, 2004, vol. 7, no. $1-2$, p. 57-62.

WISNIEWSKI, Jean-Pierre; FRANGNE, Nathalie; MASSONNEAU, Agnès and DUMAS, Christian. Between myth and reality: genetically modified maize, an example of a sizeable scientific controversy. Biochimie, November 2002, vol. 84, no. 11, p. 1095-103. 